\title{
Investigation of the Influence of Internal Control System Factors on the Financial Stability of Companies (Review)
}

\section{Larisa Ponomareva}

Assistant of the Department of Audit, Accounting and Finance

ORCID

E-mail: lara65a@yandex.ru

Novosibirsk State Technical University, Novosibirsk, Russia

Journal of Corporate Finance Research, Vol. 15, No. 2, pp. 66-76 (2021)

For citation: Ponomareva, L. (2021) "Investigation of the Influence of Internal Control System Factors on the Financial Stability of Companies (Review)", Journal of Corporate Finance Research | ISSN: 2073-0438, 15(2), pp. 66-76. doi: 10.17323/j.jcfr.2073-0438.15.2.2021.66-76.

Received 15 April 2021 | Peer-reviewed 23 April 2021 | Accepted 24 April 2021 


\section{Abstract}

The quality of internal control systems can have a significant impact on decision-making by users of financial information as well as on the financial position of organisations and on negative economic consequences of economic activity (bankruptcy, fictitious audit reports, etc.). The tools for ensuring the financial stability and solvency of a company are largely determined by the processes developed, implemented and maintained within its internal control system. In turn, the quality of the internal control system and its ability to respond quickly to emerging threats to reduce financial stability depend on external and internal factors affecting the system itself. We believe that negative consequences are typical for Russian organisations due to the insufficient study of these factors.

The goal of this paper is to investigate the influence of the external and internal factors of internal control systems on the financial stability and solvency of Russian organisations based on a review of foreign publications.

This paper has the following targets: (a) identifying the external and internal factors of internal control systems based on a review of foreign studies of the determinants of internal control systems, (b) identifying the characteristic factors of Russian organisations and (c) developing a methodology for assessing the dependence (relationship) between the characteristic factors of internal control systems and the financial indicators of Russian organisations.

Our research hypothesis is that the high level of economic crimes, bankruptcies and other negative economic consequences of low financial stability and solvency of organisations in Russia is due to the weak elaboration of factors affecting the internal control systems of organisations.

To achieve our research goal, we conducted a systematic review of foreign (Chinese, US and European) publications. The selection criteria for publications were indexability in Scopus and the Web of Science and ranking by citation level. Our research question was the influence of external and internal factors on the quality of the internal control systems of organisations. We began our literature review with the year 2014 which witnessed the appearance of studies of the results of a ten-year application of the COSO Concept: Internal Control and the Sarbanes-Oxley Act. The literature review allowed us to identify the external and internal factors affecting the internal control systems of foreign organisations. This separation is due to the fact that internal factors depend, as a rule, on the activities of the organisation, which can manage them in order to improve the quality of its internal control system and influence financial stability and solvency. External factors do not depend on the activities of the organisation, and the task of the management is to monitor risks and to respond to changes in the external environment promptly in order to minimize the negative impact on the quality of the internal control system.

Russian companies do not publish similar reports on the quality of their internal control system, which represents a significant limitation of our research. We identify the following characteristic factors for Russian organisations: external audit, state, and market factors (external factors) and the characteristics of the management board, the CEO and the board of directors, the ownership structure, and the organisation of the internal control / audit system (internal factors). In addition, the prospects for studying the impact of these factors on the internal control systems and the financial stability and solvency of organisations are outlined. A methodology for assessing the dependence (relationship) between the factors of the internal control systems and the financial indicators of Russian organisations is developed.

Key words: internal control system, ICS, ICS determinants, external factors, internal factors, finance 


\section{Introduction}

In recent years, the study of the external and internal determinants of internal control systems has been gathering pace due to the expanding experience of applying the COSO Concept: Internal Control and the Sarbanes-Oxley Act (section 302 of Corporate Responsibility for Financial Reports, section 404 of Management Assessment of Internal Controls). In most cases, researchers divide countries into three categories: countries regulating internal control system reports on the basis of the Sarbanes-Oxley Act, countries regulating internal control system reports along the American model, and countries which do not regulate this sphere at all. The regulation system influences the quality of internal control systems (ICSs); for this reason, analysis gives different results in different countries. Researchers have also identified various factors that have an impact on internal control systems and their reports, depending on national specifics. They include external factors such as external audit, national culture, market environment, and the model of internal control system regulation and internal factors such as characteristics of the CEO and the management board committee, internal audit, and ownership structure [1].

Practical issues related to determinants and economic after-effects of the quality of internal control systems have become relevant in Russia. This is related to a great number of modified auditor's opinions, detected fraudulent auditor's opinions, increasing company and especially bank bankruptcies, and the spread of fraud. Over the past decade, companies have increasingly had to grapple with economic crimes. According to the Global Economic Crime and Fraud Survey 2018 [2] prepared by the accounting firm PricewaterhouseCoopers, the following types of fraud prevail in Russia: misappropriation of assets, bribery and corruption, and procurement fraud. According to a poll conducted in Russia, $41 \%$ of respondents whose companies had suffered from economic crimes over the previous two years said that their losses had amounted to $\$ 100,000$ [2]. Audit results confirm that the misrepresentation of financial statements takes place on a regular basis. According to reports of the Ministry of Finance of the Russian Federation, approximately $20 \%$ of audit reports over the past five years have been issued with a modified opinion, which was represented in most cases as a qualified opinion [3].

Global Economic Crime and Fraud Surveys indicate that internal control mechanisms are most effective in detecting unscrupulous practices. Thus, the identification of external and internal factors, the study of their influence on internal control systems and their correction on the basis of the detected factors make it possible to decrease the likelihood of modified auditor's opinions, bankruptcy and other negative consequences resulting from low-quality internal control systems.

In view of this we propose the following research hypothesis: in Russia, there is a high level of economic crimes, bankruptcies and other negative economic consequences of the low financial stability and solvency of organisations due to an insufficient understanding of factors affecting the internal control systems of organisations. The purpose of this paper is to investigate the influence of external and internal factors of internal control systems on the financial stability and solvency of Russian organisations based on a review of foreign publications

Our study has the following targets: identifying the external and internal factors of internal control systems based on a review of foreign studies of the determinants of such systems, identifying the characteristic factors of Russian organisations, and developing a methodology for assessing the dependence (relationship) between characteristic factors of internal control systems and the financial indicators of Russian organisations.

The paper consists of three sections that study the influence of internal factors on the internal control system, the influence of external factors on the internal control system, and the characteristics of the internal control systems of Russian companies.

To attain this goal, we make a systematic review of foreign publications (China, Europe and the USA). The following selection criteria were used for publications: published in 2014-2020 (the beginning of this period witnessed the publication of studies about the results of a ten-year application of the COSO Concept: Internal Control and the Sarbanes-Oxley Act), indexability in Scopus and the Web of Science, ranking by citation level, and international scope (the sample comprises studies from the USA, Europe, China and other countries, making it possible to identify similarities and differences in conclusions about the influence of similar factors on internal control systems due to the specifics of national regulations and old ways).

\section{Study of the Influence of Internal Factors on the Internal Control System}

In order to test our hypothesis and identify the ICS characteristics of Russian companies, we shall make a detailed review of foreign studies of the influence of internal corporate factors on internal control systems.

An analysis of literature indicates that the main internal factors are the characteristics of the CEO, the board of directors, the audit committee, and the ownership structure (Table 1).

\section{Characteristics of the CEO, Board of Directors and Management Board}

The board of directors and audit committee play an essential role in establishing the internal control system. Audit committees control the audit of a company, analyse major shortcomings and monitor remedial measures. The board of directors assumes the final responsibility for the supervision of the internal control system.

CEO characteristics (for example, individual approach or cooperation with the board of directors, management style 
(power), ownership of company shares) may also have an impact on ICS quality. For example, a powerful CEO may jeopardize the ability of the board of directors to control management decisions and weaken the internal control and corporate monitoring systems in order to serve his/ her own interests.

Do the characteristics of the board of directors and internal auditors influence the reliability of internal control systems? Studies conducted in the USA by Balsam, Jiang and $\mathrm{Lu}$ (2014) demonstrate that the characteristics of the board of directors (size and independence) and the audit committee (financial examination and size) have no significant impact on the disclosure of information about the weaknesses of the internal control system (as per SOX 404) [1]. However, Chen et al. (2017) believe that the independence of the board of directors has a negative impact on the disclosure of information about the shortcomings of the internal control system and that this negative relation defines to a greater extent the double nature of CEOs [1]. Probably, the contradicting results are related to the different regulation systems in the USA and China as well as to the different time periods of the studies.

How does the CEO's gender influence the quality of the internal control system? In recent years, there have appeared a number of studies that may be used to trace the impact of gender diversity of the board of directors and audit committee on the quality of the internal control system. Parker et al. (2017) examine the question of whether the gender of auditors and board members influences ICS quality. Their results show that the share of women on the audit committee is positively related to the probability of the disclosure of information on ICS weak points in reports. For the board of directors, this relation is negative [5]. Chen et al. (2016) also suggest that the percentage of women on the board of directors has a negative relation to the probability of the disclosure of information about ICS shortcomings [6].

In comparison with earlier research, the aforementioned papers largely confirm that ICS quality has a direct relation to the characteristics and composition of the board of directors. It complies with good management practice. Studies on audit committees and the ICS also support the opinion that positive aspects of audit committees (such as expert knowledge and independence) are related to higher ICS quality. Studies of the influence of CEO characteristics and new studies of the influence of women CEOs on ICS quality are more equivocal. The conclusions depend on the country of study, the national culture and the customary ways of doing business.

\section{Ownership Structure}

The characteristics of the ownership structure (family ownership, ownership concentration) have a significant impact on corporate management practices and, hence, on risk management and internal control systems due to the ability/inability of some persons to influence decision making.

How does family ownership influence the quality of the internal control system in various countries? Bardhan (2015) and Weiss (2014) studied the impact of family ownership on ICS quality in the USA and Israel, respectively. Weiss (2014) points out that family ownership is, to a large extent, associated with a smaller number of material shortcomings of the ICS disclosed in the reports of Israeli companies [7]. Bardhan (2015) provides evidence that American family firms have lower ICS quality (SOX, section 404) than non-family ones [8]. Obviously, the difference in these researchers' conclusions is explained by specifics of the national cultures of the studied countries.

\section{Internal Auditors}

The audit committee plays an important role in assuring the proper quality and efficiency of corporate governance, creating and maintaining the company's business value and improving its investment attractiveness. The main function of the audit committee is to provide assistance to the board of directors in exercising efficient control, including the following factors:

- Completeness, accuracy and reliability of reports.

- Efficiency of corporate governance, risk management and the internal control system.

- Efficiency of internal audit.

- Quality of internal audit.

- Counteracting the unscrupulous practices of employees.

Thus, the internal audit department plays an essential role in monitoring and uncovering the shortcomings of the internal control system and informing the senior executive management about them so that remedial measures are taken in due time. The aforementioned studies indicate that the improvement of internal audit is related to the improvement of the quality of the internal control system. 
Table 1. Internal determinants of the internal control system (ICS)

Authors

Characteist

Lin et al. (2014) [1]

CEO characteristics and ICS shortcomings

Statutory regulation / used reports

Main results

Campbell et al. (2016) [1]

Professional community of the senior executive manag -

U nanequality Chen, Knechel et al. (2017) [1] $\quad \begin{aligned} & \text { Independence of the board of directors and the probability of } \\ & \text { including information on ICS shortcomings in the report }\end{aligned}$

Chen, Eshleman et al. (2016) [6]

Presence of women on the management board and ICS

shortcomings

USA

Presence of women on the audit committee and management USA

Pakey et al. (2017) [3]

board and disclosure of ICS shortcoming

Hay et al. (2014) [1]

Independent directors on the board and ICS quality

China

Shen et al. (2020) [9]

Rural origin of the director (as well as his/her gender, age, and education) and the internal control system

China

Corporate integrity and shortcomings of internal control

China

Individual characteristics of the members of the board of control quality

$\mathrm{Lu}, \mathrm{Cao}(2018)[11]$

Independence of the board of directors, size of the board of directors, institutional ownership and ICS disclosure

Agyei-Mensah (2016) [12

Characteristics of the board of directors, audit committee and ICS disclosure

Michelon et al. (2015) [1]

Great Britain

ancos

Bardhan (2015) [4]

Weiss (2014) [7]

Family ownership and ICS shortcomings

USA

Family ownership and ICS shortcomings

Israel

Ji et al. (2015) [1] Ownership structure and voluntary disclosure of ICS shortcomings

China

nies

SOX 404, disclosure of ICS shortcomings

SOX 404, disclosure of ICS shortcomings

SOX 404, disclosure of ICS shortcomings

SOX 404, disclosure of ICS shortcomings

SOX 404, disclosure of ICS short-

Voluntary disclosure of audit reports concerning the ICS

tements of Chinese listed compa-

Data of polls about corporate integrity

\section{Internal audit quality}

Mazza and Azzali (2015) [1]

Influence of internal audit quality on the gravity and resistance of ICS shortcomings

China

Ifrers reports

Index of ICS information disclosure

SOX 404, disclosure of ICS short-

comings

SOX 302, disclosure of ICS short-

comings

Informative analysis of ICS reports

Examination of internal auditors

Influence of the characteristics of internal audit on the efficiency of internal control
Italy

China
Data on Taiwanese companies comings

Chang et al. (2019) [13] control system shortcomings

CEO security (length of appointment) and age are related negatively to ICS quality (the older the director, the lower the ICS quality)

Executive relationships (joint ownership by the $\mathrm{CEO} /$ chief financial officer) are related negatively to the probability of ICS shortcomings

The independence of the board of directors is related negatively to the disclosure of shortcomings of the

The share of women on the audit committee (management board) is significant and positively (negatively) related to the probability of disclosing ICS shortcomings. The influence has not been defined.

Independent directors on the board of directors improve ICS quality.

The rural origin of the CEO may improve significantly the quality of corporate internal control. At the same time, when the CEO is a woman, the positive influence of the CEO's rural origin on the quality of the internal control is not apparent; however, when the $\mathrm{CEO}$ is older and has a higher education, the positive influence of the CEO's rural origin on the quality of corporate internal control becomes more apparent.

Corporate integrity is related very significantly and negatively to internal control shortcomings. The negCotween corporate integrity and internal control shortcomings is more significant in cases of the relation between corporate integrity and the the quality of intern control

Internal control quality is better, shortcomings of internal control are reduced, and elimination of shortcomings is more likely in companies whose chairman and members of the board of directors have higher qualifications. Moreover, the right of ownership has a restraining influence on the interrelation between the characteristics of the board of directors and internal control.

Only the independence of the board of directors has a significant positive influence.

The double nature of the CEO has a negative impact on the disclosure of ICS shortcomings. An expert chairman of the audit committee has a positive influence.

Family firms show greater ownership shortcomings of the internal control system that non-family compaThe size of the board of directors and ownership concentration have a negative impact on the voluntary disclosure of ICS shortcomings, while the expertise of the audit committee has a positive impact.

The improvement of internal audit quality is related to a decrease in the gravity and resistance of control

Internal audit assists management in improving internal control. A larger internal audit group may increase the efficiency of internal audit, while the competence of an internal auditor is positively related to the efficiency of the internal control of compliance, not operations 


\section{Study of the Influence of External Factors on the Internal Control System}

In order to test our hypothesis and identify the ICS factors characteristic of Russian organisations, we shall consider in greater detail foreign studies of the influence of external factors on the internal control system.

A literature analysis shows that the main external factors are external audit, national culture and market factors (Table 2).

\section{Variables Related to Audit}

Not only internal but also external audit has been shown to have a significant impact on company operations in general and on the internal control system in particular. For example, it has been argued that an improvement in auditor quality is positively associated with ICS performance. Auditors' IT expertise and in-depth knowledge of their client companies allow them to conduct advanced auditing procedures and make the corresponding tests to detect risk areas. This is likely to enhance audit quality and reduce the probability of ICS shortcomings. The auditor type (Big 4 or non-Big 4) may also have an impact on ICS quality, insofar as Big 4 auditors tend to be more independent due to their diversified client portfolio and exert more pressure on management to improve the ICS. Thus, organisations that are subject to mandatory external audit or commission voluntary audit improve the quality of their internal control systems.

How does payment for auditing services influence the quality of the internal control system? There are a lot of studies that consider the impact of a flawed internal control system on the quality of financial statements, decision making and audit. Buslepp et al. (2019) attempted to develop an alternative measure of internal control quality. They assumed that an erroneous classification of fees related to audit is indicative of a low quality of internal control in disclosures of annual reports. Due to lower-quality internal control, companies that erroneously classify fees related to audit are more likely to inform of a significant shortcoming, submit applications at an inappropriate time (a longer time lag) and pay higher fees for audit. An erroneous classification of the fees related to audit correlates with a low quality of internal control [14].

Irrespective of the country (USA, China, or Egypt), researchers register the positive influence of high-quality external and internal audit on the quality of the internal control system.

\section{Financial Analysts}

The question of the influence of financial analysts and the reports they publish on the quality of the internal control system is hardly considered in the literature, despite the fact that financial analysts play an important role as intermediaries between companies and investors. By studying a company and estimating its profit, financial analysts provide an additional mechanism of external monitoring that can lead to the imposition of severe restrictions on company management in order to improve ICS quality.

Mao and Yu (2015) studied the interrelation between the beginning of analyst forecasting of cashflows and the rise in ICS quality in the USA. They concluded that, after analysts started to make forecasts on cashflow movements, companies began to reveal a smaller number of ICS shortcomings as per SOX 404, implying that analysts motivate managers to focus on the quality of the internal control system [1].

Nevertheless, the influence of financial analyst activity and reports on the quality of the internal control system requires additional study.

\section{National Culture}

According to Hofstede's definition (2001) that places special emphasis on individualism, the avoidance of instability and power distance characteristics, the national culture may also influence ICS quality [15]. Managers operating in countries with a higher level of individualism care more for their own interests than for the welfare of shareholders and the demands of affected parties. They are more inclined to use discretionary instruments to serve their own purposes. A higher level of individualism and power distance has a positive relation with ICS shortcomings, while a higher level of instability avoidance decreases the probability of shortcomings in the internal control system.

Hooghiemstra's study of the internal control reports of companies from 29 countries and Kanagaretnam's study of SOX 404 reports on the disclosure of ICS shortcomings of US-incorporated companies from 39 countries show that individualism has a positive impact on the disclosure of information about ICS quality [16].

\section{Regulatory and Market Factors}

How does government regulation influence companies' operations in general and their internal control systems in particular? A high level of government regulation forces companies to comply with rules and guiding principles in order to survive. Market competition makes it more likely that a company characterized by a high cost of goods, work and services will be liquidated. The implementation of a high-quality internal control system requires financial resources, and so companies with lower profitability have less opportunities to improve their internal control systems.

How do the characteristics of the market on which the company operates influence its internal control system? In the USA, Kim et al. (2015) considered the influence of three factors on competition on the product market (Herfindahl-Hirschman index, the greatest concentration coefficient (for four companies) and the industry leader indicator) in order to evaluate the quality of internal control systems. They showed that companies operating on highly competitive markets are characterized by lower ICS quality (SOX, section 404) [1]. 
Table 2. External Determinants of the Internal Control System (ICS)

\begin{tabular}{|c|c|c|c|c|}
\hline Authors & Factors of the internal control system (ICS) & Country & Statutory regulation / used reports & Main results \\
\hline \multicolumn{5}{|l|}{ External audit } \\
\hline López et al. (2014) [19] & Auditor type and ICS quality & USA & $\begin{array}{l}\text { Internal control shortcomings disclosed in } \\
\text { A-133 information letters of auditor's opin- } \\
\text { ions of health care companies }\end{array}$ & Companies verified by Big 4 auditors have higher ICS quality \\
\hline De Simone et al. (2015) [1] & Rendering of tax services by an auditor and ICS quality & USA & $\begin{array}{l}\text { SOX } 302 \text { and } 404 \text {, ICS shortcomings dis- } \\
\text { closure }\end{array}$ & $\begin{array}{l}\text { Companies which purchase tax and non-audit services disclose major shortcomings of the ICS less } \\
\text { frequently }\end{array}$ \\
\hline Albring et al. (2018) [20] & $\begin{array}{l}\text { Unexpected fees and financial shortcomings of internal } \\
\text { control }\end{array}$ & USA & SOX 404, ICS shortcomings disclosure & Unexpected fees are related to shortcomings of the ICS at the corporate level \\
\hline $\begin{array}{l}\text { Chen, Gul et al. } \\
\text { (2016) [21] }\end{array}$ & $\begin{array}{l}\text { Term of auditor's powers and geographic proximity to the } \\
\text { customer and ICS shortcomings }\end{array}$ & USA & SOX 404, ICS shortcomings disclosure & $\begin{array}{l}\text { Companies whose auditors are involved in their activities in the long term and which are geographi- } \\
\text { cally closer to auditors have less serious problems with ICS shortcomings }\end{array}$ \\
\hline $\begin{array}{l}\text { Haislip et al. } \\
\text { (2016) [1] }\end{array}$ & Auditor's IT experience and ICS shortcomings & USA & SOX 404, ICS shortcomings disclosure & Auditor's IT experience has an inverse relation to ICS shortcomings \\
\hline $\begin{array}{l}\text { López and Rich } \\
\text { (2017) [19] }\end{array}$ & $\begin{array}{l}\text { Geographical distance between municipalities of the USA } \\
\text { and their external auditors and ICS quality }\end{array}$ & USA & $\begin{array}{l}\text { A-133 information letters, ICS shortcom- } \\
\text { ings disclosure }\end{array}$ & $\begin{array}{l}\text { Geographical distance between municipalities of the USA has a positive impact upon disclosure of } \\
\text { ICS exceptions }\end{array}$ \\
\hline Buslepp et al. (2019) [14] & $\begin{array}{l}\text { Erroneous classification of fees related to audit and short- } \\
\text { comings of internal control }\end{array}$ & USA & SOX 404, ICS shortcomings disclosure & $\begin{array}{l}\text { In accordance with a lower quality of internal control, companies which classify audit-related fees } \\
\text { erroneously are more likely to report major shortcomings, submit applications at an inappropriate } \\
\text { time and pay higher fees for audit. Erroneous classification of fees related to audit is defined by a low } \\
\text { quality of internal control }\end{array}$ \\
\hline Xudong Ji et al. (2018) [22] & $\begin{array}{l}\text { Payment for audit and shortcomings of the internal control } \\
\text { system }\end{array}$ & China & $\begin{array}{l}\text { Voluntary disclosure of auditor's opinions } \\
\text { about the ICS }\end{array}$ & $\begin{array}{l}\text { Payment for audit is related positively to detected shortcomings of internal control. In particular, it is } \\
\text { significantly related to non-financial reporting but has no relation to financial statements }\end{array}$ \\
\hline Khlif and Samaha (2016) [23] & $\begin{array}{l}\text { Activity of the audit committee and ICS quality and influence } \\
\text { of the scope of external audit }\end{array}$ & Egypt & Examination of external auditors & $\begin{array}{l}\text { The activity of the audit committee is related positively to ICS quality, and such interrelation is more } \\
\text { characteristic of audits performed by Big } 4 \text { auditors }\end{array}$ \\
\hline \multicolumn{5}{|l|}{ Financial Analysts } \\
\hline Mao and $\mathrm{Yu}(2015)[1]$ & Predictive analysis of cash flows and ICS quality & USA & SOX 404, ICS shortcomings disclosure & Forecasts of cash flow movements reduce the possibility of financial ICS shortcomings \\
\hline \multicolumn{5}{|l|}{ National Culture } \\
\hline $\begin{array}{l}\text { Hooghiemstra et al. } \\
\text { (2015) [1] }\end{array}$ & $\begin{array}{l}\text { Individualism and uncertainty avoidance and voluntary dis- } \\
\text { closure of the ICS }\end{array}$ & 29 countries & Analysis of ICS reports & $\begin{array}{l}\text { Individualism (uncertainty prevention) has a positive (negative) influence on the disclosure of ICS } \\
\text { information }\end{array}$ \\
\hline $\begin{array}{l}\text { Kanagaretnam et al. } \\
\text { (2016) }[16]\end{array}$ & $\begin{array}{l}\text { National culture (individualism, uncertainty avoidance and } \\
\text { power distance) and ICS shortcomings }\end{array}$ & $\begin{array}{l}\text { Companies from } \\
39 \text { countries } \\
\text { incorporated in } \\
\text { the USA }\end{array}$ & SOX 404, ICS shortcomings disclosure & $\begin{array}{l}\text { Individualism and power distance are related positively while uncertainty avoidance is related nega- } \\
\text { tively to the disclosure of ICS shortcomings }\end{array}$ \\
\hline \multicolumn{5}{|l|}{ Governmental and Market Factors } \\
\hline Kim and Kim (2015) [1] & Competition on the product market and ICS quality & USA & SOX 404, ICS shortcomings disclosure & Companies active on competitive markets have lower ICS quality \\
\hline Bryan (2017) [17] & $\begin{array}{l}\text { Power of trade unions and quality of audits and internal } \\
\text { control }\end{array}$ & USA & SOX 404, ICS shortcomings disclosure & $\begin{array}{l}\text { Trade unions have reasons to request high-quality inspections and reliable internal control systems, } \\
\text { because they rely on financial information when conducting negotiations for signing collective bar- } \\
\text { gaining agreements. Nevertheless, organised labour motivates managers to commission lower-quality } \\
\text { audits and provide weaker internal control in order to have more influence over the content of finan- } \\
\text { cial information submitted to trade unions. The power of trade unions is related to high audit quality } \\
\text { and better internal control. }\end{array}$ \\
\hline Zhang and Chen (2016) [18] & $\begin{array}{l}\text { Competition on the product market and ICS quality. Does } \\
\text { government ownership mitigate this ratio? }\end{array}$ & China & $\begin{array}{l}\text { Analysis of annual reports (index of ICS } \\
\text { quality) }\end{array}$ & $\begin{array}{l}\text { Intensive competition on the product market is related to higher ICS quality. This relation is stable } \\
\text { only for companies with non-governmental ownership. }\end{array}$ \\
\hline
\end{tabular}


At the same time, Zhang and Chen (2016) demonstrated that the intense competition on the product market in China leads to a higher level of disclosure of information about the internal control system [18]. National differences may be a possible reason for these contradictory conclusions.

Do trade unions and their activities influence the quality of the internal control system? Bryan (2017) makes a classification on the basis of this category. Trade unions have reasons to request high quality inspections and reliable internal control systems, because they rely on financial information when conducting negotiations for signing collective bargaining agreements. Nevertheless, organised labour motivates managers to employ lower-quality audits and set up weaker internal controls in order to have more influence on the financial information submitted to trade unions. The power of trade unions is related to high audit quality (and high payments for audit) and better internal control (smaller number of major shortcomings) [17].

Thus, quality of the internal control system is related directly to the level of government regulation of corporate operations in general and the internal control system in particular, the level of non-government regulation (trade union activities), and the level of competition on the market.

Our review of foreign literature identified the following factors as having a significant impact on the internal control system: characteristics of the director, board of directors and management board, ownership structure, and internal audit quality (internal factors) and external audit, financial analysts, national culture, governmental and market factors (external factors). For some characteristics (for example, women occupying senior management positions), contradictory results were obtained about their influence on the corporate internal control system. The dif- ferences are due to the time periods of the studies, national traditions of doing business, and the specific nature of the regulation of internal control in the USA and some other countries. The majority of conclusions about the strength and type of relation between the internal control system and external / internal factors were obtained on the basis of corporate reports about the state of the internal control system made in conformity with the Sarbanes-Oxley Act and other reports: independent evaluation of the control tools System and Organisation Controls (SOC, previously: Service Organisation Controls) in accordance with SSAE 18, ISAE 3402 and other standards [24].

\section{The Internal Control System of Russian Organisations: Developing a Methodology for Assessing the Influence of the Internal Control System Factors on the Financial Stability and Solvency of Russian Organisations}

While internal control is obligatory in Russia today [25], requirements for internal control systems and the obligation to prepare reports have not been codified by law. The greatest problem of our study in this domain is the absence of statistics in Russia that could be used to determine the influence of factors on the internal control system in the national environment and hence their influence on corporate finance.

Table 3 presents internal and external factors which, in the author's opinion, influence or may influence the internal control systems of Russian companies.

Table 3. Determinants of the internal control systems of Russian organisations

ICS factors Main results

Characteristics of the man- The existence of a board of directors has a positive influence on the agement board quality of the internal control system

Organisations managed by directors (boards of directors) of middle age (younger than 40) are more likely to have internal control shortCharacteristics of the CEO comings. The greater the participation of the director (members of and board members

Internal the board of directors), the lower the quality of the internal control system. In contrast, the higher their education attainment and experience, the less likely the existence of ICS shortcomings

Ownership structure

The influence of private / government / mixed structure has not been determined

Arrangement of the internal The existence of internal control / audit departments has a positive control / audit system impact on ICS quality 
ICS factors

\section{Main results}

Obligatory audit has a positive impact on the quality of the internal

External audit control system. With regard to audit company type (Big 4, non-Big 4), companies examined by Big 4 auditors have higher-quality ICS

External

Statutory regulation of the industry (specific laws and regulations): the tighter the governmental control, the higher the ICS quality. Or-

Governmental and market ganisations which maintain accounting and write up account statefactors ments according to IFRS are less likely to have major ICS shortcomings. The higher the competition on a market, the higher the quality of the internal control system
The conclusions concerning the characteristics of the management board and CEO are confirmed by the data of Russian surveys about economic crimes and fraud. Approximately $50 \%$ of economic crimes in Russia are committed by employees in their own organisations - in particular, by senior executive managers (39\%) and middle-ranking managers (47\%) and, more specifically, by finance department employees [1]. The typical perpetrator of fraud is a male of age 31-40 with a tertiary degree and professional experience of three-five years. On the basis of this data, we can make the conclusion that, when an organisation is managed by such employees, it has a worse internal control system. This enables them to commit fraud.

It should be noted that, in Russia, $41 \%$ of respondents whose companies had suffered from economic crimes over the preceding four years said that their losses had amounted to $\$ 100,000$ [1]. This confirms the assumption made at the beginning of our study about the insufficient understanding of factors that influence the internal control systems as well as the financial stability and solvency of Russian companies.

To test our conclusions on a real-life case, we chose the pharmaceutical industry on account of its high social significance. Most pharmaceutical distributors make up statements of accounts as per IFRS. Such annual reports are subject to obligatory audit. We analysed reports of key pharmaceutical distributors incorporated and operating on the market of the Siberian Federal District (selection criteria: type of activity - wholesale in pharmaceutical products; principal economic activity code (OKVED (Russian National Classifier of Types of Economic Activity)) 46.46; revenue for 2017 and/or 2016 and/or 2018 - over RUB 1 million). However, to avoid preparing (or publishing) reports about their internal control systems, some companies include only information on internal audit in their annual reports, while issues related to the internal control system in auditor's opinions are not considered to be important.

In this section of our study, we evaluate the dependence (interrelation) between factors of the internal control systems and the financial indicators of the chosen companies. We apply the methodology presented in Figure 1.

In order to apply this methodology, we take liquidity as the characteristic "problematic" indicator. A financial analysis of pharmaceutical distributor operations demonstrates that the majority of companies from the Siberian Federal District show a significant negative deviation from average market liquidity indicators across the country (average industry indicators: current liquidity ratio -3.02 , quick liquidity ratio -2.02 , absolute liquidity ratio -0.54 ).

Figure 1. Methodology for assessing the dependence (interrelation) between the factors of the internal control systems and the financial indicators

\begin{tabular}{|c|c|}
\hline \multicolumn{2}{|c|}{ Identifying the factors which influence the internal control systems of the chosen companies } \\
\hline $\begin{array}{c}\text { Verifying the disclosure of information about } \\
\text { risks related to the internal control system in the } \\
\text { reports of the chosen companies }\end{array}$ & $\begin{array}{c}\text { Taking a company with the most complete disclo- } \\
\text { sure of information about risks in its reports as a } \\
\text { standard }\end{array}$ \\
\hline $\begin{array}{c}\text { Evaluating and ranking the disclosure of information las it has changed over the years) } \\
\text { about risks in the reports of the chosen companies in comparison with the standard }\end{array}$ \\
\hline \\
\hline $\begin{array}{c}\text { Detecting the financial indicator characteristic which the chosen companies can control } \\
\text { through their financial management system }\end{array}$ \\
$\begin{array}{c}\downarrow \\
\text { Developing a model and assessing the significance of the relation between the disclosure of } \\
\text { information about risks (related to the factors of the internal control system) and the char- } \\
\text { acteristic indicator (financial stability and solvency) }\end{array}$ \\
\hline
\end{tabular}


If a significant and direct dependence (interrelation) of the chosen indicators is observed (i.e. the higher the assessment of disclosure of information on risks related to the factors of the internal control system, the higher the liquidity indicators of the chosen companies), our hypothesis that the high level of economic crime and fraud, bankruptcies and other negative economic after-effects of low financial stability and solvency of Russian organisations is due to an insufficient understanding of the factors that influence the internal control systems of organisations will be proven.

\section{Conclusion}

Despite some controversy about the results of a systematic review of foreign publications, we identified the external and internal factors of internal control systems and defined their influence on the latter (taking national specifics into account in some cases). Companies can control the following internal factors to improve the quality of their internal control systems: characteristics of the CEO, board of directors and management board; ownership structure; and quality of internal audit. The following external factors are characteristic of the internal control systems of foreign companies, according to our analysis: external audit, financial analysts, national culture, and governmental and market factors. It should be noted that government regulation of the internal control system is one of the most important governmental factors determining differences in the results of studies in various countries.

At the beginning of this paper, we divided countries into three categories: countries regulating the reports of the internal control system by the Sarbanes-Oxley Act, countries regulating reports of the internal control system along the American model, and countries which do not regulate this sphere at all. However, Russia does not belong to any of these categories. Federal Law No. 402-FZ "On Accounting" [25] sets down the requirement of conducting internal control, and some instructional guidelines about the disclosure of specific aspects of internal control have also been introduced. However, the requirements for the internal control system and the obligation to prepare reports have not been strictly codified by law, in contrast to countries that adopted the Sarbanes-Oxley Act or similar laws. In this regard, the absence of the required information impedes the study of the influence of external and internal factors on the internal control systems of Russian organisations. We identified the following characteristic factors of Russian companies: external audit and governmental and market factors (external factors) and the characteristics of the management board, the CEO, and members of the board of directors, ownership structure, and the arrangement of the internal control / audit system (internal factors), although the type of influence has not been identified for all factors. We then proposed a methodology for assessing the dependence (relationship) between the factors of the internal control system and the financial indicators.
If the results of the proposed methodology show a significant and direct dependence (relationship) between the chosen indicators (i.e. the higher the assessment of the disclosure of information on risks related to the factors of the internal control system, the higher the liquidity indicators of the chosen companies), the hypothesis that a high level of economic crime and fraud, bankruptcies and other negative economic after-effects of low financial stability and solvency of Russian organisations is due to an insufficient understanding of the factors which influence the corporate internal control system will be proven.

Finally, it should be noted that the goal of the paper of investigating the influence of external and internal factors of the internal control system on the financial stability and solvency of Russian organisations based on a review of foreign publications has been achieved. The limitations of our study include the small sample of companies (the leading pharmaceutical distributors of the Siberian Federal District) and the lack of a database of corporate reports on internal control systems.

\section{References}

1. Chalmers K., Hay D., Khlif H. Internal control in accounting research: A review. Journal of Accounting Literature.2019;42:80-103. https://doi.org/10.1016/j. acclit.2018.03.002

2. Anti-fraud: What measures are companies taking? Russian economic crime survey 2018. Moscow: PwC; 2018. 28 p. URL: https://www.pwc.ru/ru/forensicservices/assets/PwC-recs-2018-rus.pdf (accessed on 10.04.2020). (In Russ.).

3. Key indicators of the audit services market in the Russian Federation. Ministry of Finance of Russia. URL: https://www.minfin.ru/ru/perfomance/audit/ audit_stat/MainIndex (accessed on 10.04.2020). (In Russ.).

4. Bardhan I. The quality of internal control over financial reporting in family firms. Accounting Horizon. 2015;29(1):41-60. https://doi.org/10.2308/ acch-50935

5. Parker R.J., Dao M., Huang H.-W., Yan Y.-C. Disclosing material weakness in internal controls: Does the gender of audit committee members matter? Asia-Pacific Journal of Accounting \& Economics.2017;24(3-4):407-420. https://doi.org/10.1 080/16081625.2015.1057190

6. Chen Y., Eshleman J.D., Soileau J.S. Board gender diversity and internal control weaknesses. Advances in Accounting. 2016;33:11-19. https://doi. org/10.1016/j.adiac.2016.04.005

7. Weiss D. Internal controls in family-owned firms. European Accounting Review. 2014;23(3):463-482. https://doi.org/10.1080/09638180.2013.821814 
8. Bardhan I. The quality of internal control over financial reporting in family firms. Accounting Horizon.2015;29(1):41-60. https://doi.org/10.2308/ acch-50935

9. Shen H., Xiong H., Zheng S., Hou F. Chief executive officer (CEO)'s rural origin and internal control quality. Economic Modelling.2021;95:441-452. https:// doi.org/10.1016/j.econmod.2020.03.011

10. Shu W., Chen Y., Lin B., Chen Y. Does corporate integrity improve the quality of internal control? China Journal of Accounting Research.2018;11(4):404-427. https://doi. org/10.1016/j.cjar.2018.09.002

11. Lu Y., Cao Y. The individual characteristics of board members and internal control weakness: Evidence from China. Pacific-Basin Finance Journal. 2018;51:75-94. https://doi.org/10.1016/j. pacfin.2018.05.013

12. Agyei-Mensah B.K. Internal control information disclosure and corporate governance: Evidence from an emerging market. Corporate Governance. 2016;16(1):79-95. https://doi.org/10.1108/CG-102015-0136

13. Chang Y.-T., Chen H., Cheng R.K., Chi W. The impact of internal audit attributes on the effectiveness of internal control over operations and compliance. Journal of Contemporary Accounting \& Economics. 2019;15(1):1-19. https://doi.org/10.1016/j. jcae.2018.11.002

14. Buslepp W., Legoria J., Rosa R., Shaw D. Misclassification of audit-related fees as a measure of internal control quality. Advances in Accounting. 2019;46:100425. https://doi.org/10.1016/j. adiac.2019.100425

15. Hofstede G. Culture's consequences: Comparing values, behaviors, institutions and organisations across nations. International Journal of Cross Cultural Management. 2001;1(2):243-246. https://doi. org/10.1177/147059580112007

16. Kanagaretnam K., Lobo G.J., Ma C., Zhou J. National culture and internal control material weaknesses around the world. Journal of Accounting, Auditing \& Finance. 2016;31(1):28-50. https://doi. org/10.1177/0148558X14560897

17. Bryan D.B. Organised labor, audit quality, and internal control. Advances in Accounting. 2017;36:1126. https://doi.org/10.1016/j.adiac.2016.09.005

18. Zhang C., Chen H. Product market competition, state ownership and internal control quality. China Journal of Accounting Studies. 2016;4(4):406-432. https://doi. org/10.1080/21697213.2016.1252078
19. López D.M., Rich K.T. Geographic distance and municipal internal control reporting. Advances in Accounting. 2017;36:40-49. https://doi.org/10.1016/j. adiac.2016.08.003

20. Albring S.M., Elder R.J., Xu X. Unexpected fees and the prediction of material weaknesses in internal control over financial reporting. Journal of Accounting, Auditing \& Finance. 2018;33(4). https:// doi.org/10.1177/0148558X16662585

21. Chen, Y., Gul, F., Marisetty, V., Truong, C., \& Veeraraghavan, M. Auditor client specific knowledge and internal control weakness: Some evidence on the role of auditor tenure and geographic distance. Journal of Contemporary Accounting \& Economics, 2016, 12 114-121. https://www.researchgate.net/ publication/303979267 Auditor client specific knowledge and internal control weakness Some evidence on the role of auditor tenure and geographic distance

22. Xudong Ji, Wei Lu Internal Control Risk and Audit Fees: Evidence from China. Journal of Contemporary Accounting and Economics, 2018, 14(3). https:// www.researchgate.net/publication/326589959_ Internal_Control_Risk_and_Audit_Fees_Evidence_ from_China

23. Khlif H., Samaha K. Audit committee activity and internal control quality in Egypt: Does external auditor's size matter? Managerial Auditing Journal. 2016;31(3):269-289. https://doi.org/10.1108/MAJ-082014-1084

24. International Standards on Auditing 315. Identifying and assessing the risks of material misstatement through understanding the entity and its environment. URL: http://www.ifac.org/system/files/ downloads/a017-2010-iaasb-handbook-isa-315.pdf (accessed on 04.09.2019).

25. Federal Law dated 06.12.2011 No. 402-FZ “On accounting" (as amended on 31.12.2017). URL: http://www.consultant.ru/document/cons_doc_ LAW_122855/ (accessed on 04.09.2019). (In Russ.).

26. Market analysis in the Spark-INTERFAX system. URL: http://www.spark-interfax.ru/ (accessed on 15.09.2019). (In Russ.). 